Historic, Archive Document

Do not assume content reflects current scientific knowledge, policies, or practices. 

NETTIORK: - NBC

ORIGIN: WRC
DATE: August 7, 1943

TIME: $12: I 5-I 2: 30$ P.M.EWI

(Produced by the Food Distribution Adninistration of the Tar Food Administration, this script is ior reference only and hay not be broadcast without special permission. The title CONSUVET-TIME is restricted to network broadcasts of "this program-presenfeld R I I I more than ten years in the interests of consumers.)

\section{AUG $6-1943$}

000000000000000

1. SOUND: CASH REGISTER-RINGS THICE.... MONTY IN THE TIII

2. MAN: That's jour money buying a living in wartime.

3. SOUND: CASH REGISTER

4. TOIANT: And this is COMSUNER TIIE-helping you save some of that money.

5. SOUND: CASH REGISTER

6. IANT:

Dollars that all of us must stretch, these. days.

7. WOMAN: Dollars that are needed in War Bonds.

8. SOUND: CASH PEGISTER:

9. MAN: Yes, this is CONSUNAR TIIE bringing you, today--.-

10. WOMAN: Iisten, Rosemary, just what is this Group Two I heard you talling about to liarge?

11. WORAN II It's the second in the basic seven food groups. Group two includes Citrus Fruits, Tomatoes, raw cabbage and salad greens.

12. MAN: That's the CONSUNER TIME program for todat--the foods in Group Two-and canning some of those foods to help maise you stronger, healthier in wartime. But now-our consumer reporter--Johnny Sinith wi.th.... 
14. JOHN:

15. SOUND:

16. FREYMAIJ :

17. DAVE:

18. FREMIAN :

19. DAVE:

20. FREMIAIT:

21. DAVE:

22. FREYMAN :

23. DAVE:

24. FREMMAN:

25. DAVE:

26. FREMMAN :
As everybody knows-Tashington is a busy place these days--but few places could be busier than the kitchen of Mrs. Evelym Freyman was all day yesterday--and last evening. lirs. Freyman's husband, Dave, had worked late at the office and had dinner down torn. Then he came horne...... CANNING JAPS AND PANS RATILIII, TATER OIT, FREMAPN IS HUMUING. HUMIING OR STIGIITG UP. THEN DOOR OPENS AND CIOSES.

ATAY FRON MIKE.

That you Dave?

(AViY FROM MIKE) Yes, dear. Be rith you in just a moment.

Fine, I certainly can use you.

(CONING UP) Gee, smells mighty good in here. That have you been doing?

Fruits and vegetables-vegetables and fruits--canning --all day long. It's really been quite a day.

TeII, let's get cleaned up here--I'Il help-and we can just make the last show at the movies. It's an awful temptation, Dave-but, I can't. And why not? Can't a husband take his hard worling wife to the movies?

of course, dear-but, it's the tomatoes.

The tomatoes won't let you go to the movies?

Yes, tomatoes-from our victory garden. They've got to be camned tonight. I'm just about ready to get going on them. 

27. DAVE:

28. FREYMAN :

29. DAVE:

30. FREYMAN!

31. DAVE:

32. FREYMANT:

33. DAVE:

34. FREYIAN:

35. DAVE:

36. FREMMAN:

37. DAVE:

38. FREYMAN:
I seem to have stepped in at the perfect moment to be somewhere elsc.

(SHE DOESN'T IEAN THIS) You go on to the movies -or read your paper or something.

I'd love to but....welt... if you're working on the night shift, as well as the day shift.... g guess I can too. Here, help me drape this apron on me so I won't get all slopped up.

I didn't want to come right out and ask you to help me, Dave, ....but I'm suro glad you voluntecred. Take it all in all, I think I have a grade double A-one husband.

I love the flattery-but, what do you want me to do? Peel and spot the tomatoss before wo start canning them.

I don't have to remind you that I never canned a tomato in my life, do I?

of course not. I haven't done it for years and, years moself-not since I helped mother can some-much too long ago.

Did your mother come over today to re-educate you in canning tomatoos?

Oh no--I got the vrhole thing out of this Government folder MARTIIE CANIING OF FRUITS AND VEGETABIES. Let me take a look at it. In a minute you can--but right nor, we get busy on taking the skins off the tomatoes. 

39. DAVE:

40. FREYTIN :

41. DAVE:

42. FREYMAN :

43. DAVE:

44. FREYMAN:

45. DAVE:

46. FREYMLIT :

47. DAVE:

48. FREYMNN :

49. DAVE:

50. FREMMAN:
Any particular trick to it?

Surc. After I washod tho tomatoes, I put them in that big covered kcttle, thore, with vater. fis soon as it has boiled for 30 seconds, wo start taking the skins off the tom toes-and cutting out the stem cnds and any little spots you might see that don't look good.

I think the kettle of toratoes is boiling. That's in that other big kettlo?

They'ro my jars, and lids and jar rings for packing the tomatoes. Tho're being sterilized. Iift that kettle of tomatoos over here on the table, please, Dave.

Sure..... Ouch....

That's the troublo?

Hot!-burmed, that's all. I didn't get enough pot holdérs in nyr left hand.

Gee, I'm sorry, Dave.

Docsn't amount to much. Lot's got going on the peclins.

Better put a fork in the stom ond of each tomato-so you can hold it in your left hand as you peol it with your right hand.

O.K.... Say those skins come off just as nico as jou plcase.

The hot boiling water does that-mand also shrinks the tomatoes so we mot more in a jar.... Iess air and more tomato. 
$=\cdots \cdots$

:

$\ldots$ 
51. DAVE:

52. FREYMLN :

53. DAVE:

54. FREYIILN :

55. DATE:

56. FRETMIN :

57. DAIE:

58. FREYINN :
That do you do wi th these things after I finish pceling them?

Well, I'm just going to take the jars and lids and rubber rings of the store--so we can pack the tomatoes in as soon as you've finished peeling. Want me to lift the jars ofi the stove for $y$ u? Fou just kcep poeling. I can handle thosc jars very nicely.

If you say so. Hor many do you have?

I have ten quart jars and the fixings in here.

I don't balisve we'll have over 8 quarts to fill-but tho last minute is no time to run short. Honey, be careful with those jars. Now you just tend to the peeling. I can handle theso jars. I never droppod ono in my life.....

59. SOUTD: JAR DROPS AND SMASHES ALI TO BIEZES

60. FREYMN : (COTINUING).... Thell, only once in ny life.

61. DATE:

That happens after I skin these tomatwes and you put them in the jers?

62. FRETMN :

You see that third big kettle on the stove?

63. DAVE:

Yes.

64. FRFIMAN :

That's a conning kettle rith a wire rack inside and all full of boiling water. Then the jars are filled and sealod....thoy go in that kettle... submerged in boiling neter.

65. DiVE:

65. FREMIEN:
These tomitos aro perpotually in hot water... I'II overlock tho pun and continus by saying that the jars stay in the boiling water in the canning kettle for 10 minutes--and the $y^{\prime r e}$ done. 

67. DAVE:

68. FRETHAN:

69. DAVE:

70. FREMMN:

7I. DAVE:

72. FRETIRT:

73. DAVE:

74. FRETIN:

75. SOUND

76. LLICE:

77. JOHN:

78. ALICE:

79. JOHN:

80. ALICE:

81. JOEN:
That's right.

of course it's right-ihat do you mean, "That's right?"

I've just beon checking through this folder, WLRTIE CAMIITG OF FRUTS AND VAGMTRTIS.... and you have the process dorm pat....skipping a $\mathrm{i} e w$ details, of course. So you're checking up n ne?

Of ccurse not.... but this folder is intoresting... and simple enrugh so even a mere male, like mo, can understand wat it's talling about.

It ought to be 8:0d. The Govornment publishod itand wu can set it without chorge.

I'm sure going to onjoy these tomatnes--next winter. When it crnes to liking tomatoes, I yiold to no man. Funny thing about tomatees, Dave. It wasn't so very long age, say about 1858--just before the Civil Tar..

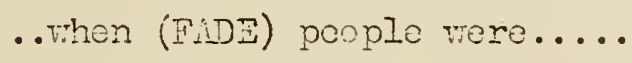

BIRDS SIMGIMG-OUT CIEIT FOP DIAIOGUE

This cpenness.... the wods.... the fiolds....sc

different from bustling, busy Cherleston, John..... It's a Iong way from Cherleston, S. C., to Minnesot?: Alice... yet, we to have our tins. Fu like them: do you net? Oh, I love ther.... Iove linnescta.... and even mre do I love ycu, John....rv husband. And I love jru, dearost. This land....so rich, so beautiful. Aye, it is.... in sumer. But the vinters are harsh. 

83. ALICE:

84. JOHN :

85. ALICE:

86. JOHN:

87. NIICE:

88. JOHIN:

89. AIICE:

90. JOHN:

91. ALICE:

92. JOHN:

93. $\triangle L I C E:$

94. JOHN:

95. ALTCE:
Yet, ours is a good house.

True, but tiv pinter sicknoss conos within the tightest houses and many of our people sicken through the long, cold months. Yet, nom, all is warmth and beauty.

John, John, lock, what is that strange plant?

By mst it is called a love apple- though some for now begin to namo it a tomato.

Love apples-I have hoard of thon.... akin to the deadly nightshade.... as poisonous as they are lovely. (InUGHTTG) Thet is an old rives tale, Nice-but still devoutly believed hereabouts.

Then, love apples are NoT pison?

I have eaten then since I was a small child. Yot, do not even now tell wy mother-for she is as certain as others that thoy are poison.

How do they tasto?

Why, herc-I'Il pluck one ior each of us. I think they're good--only I wish we had salt here with us. John, they are good-tart like an orange or a lemon. ...Though not truly the same taste.

Best not tell the neighbors you ate one, lest they think us strange.

Love apples.... tomatcos.... I shall not tell, John.... but I shall eat more of thor! unless you think thoy may harm re.

96. JOHN: from then. I ate then-even last winter and took no harn. 

97. ALICE:

98. JOHN:

99. $\triangle \mathrm{LICE}$ :

100. JOHN:

101. ALICE:

102. JOHN :

103. HIJCE:

104. JOHN :

105. ALICE:

106. JOHIV :

107. AIICE:

108. JOHN :

109. ALICE:

110. JOHN:

111. SOUND:

112. DiVE:

1I3. FREMUN:
They grow then in winter t c-r may be stored?

No... but an Englishman lately roved to Minnesota

shwed me a mothod of preserving their goodness and

freshness throughout the rinter.

In vinegar, in sugar or in brine?

No, his is a cookery process-well knom in Ingland.

A cookery process?

Yes, the love apples are cooked then hotly sealed in

jars or bottles so air may not rot them.

John, we rust gather mny love apples so I may save

ther: for our winter food.

To be eaten secretly-as I ate them last rinter.

(GiıIIY) Our very orm forbidden fruit!

Yes, Aijce. is strange thing happened last vinter-

as I ate the love apples.

What was it, John?

of all the peoplc in this cormunity, I was....by

rarself....the only one wh had not a single

touch of the winter sickness.

Do you think cating love apples prevents the winter sickness?

That, my dear, I an not learned enough to knowbut, stranger things have happened.

BIRDS SINGING- - S IT BEGINNING OF TUIS SCENE

I suppose John aveided the winter sickness because of the vitimin $\mathrm{C}$ in tonatoes.

Probably. Lack of vitamin C during winter-in cold sections-has caused a lot of "beginning scurvy." 

114. DAVT:

115. FREMMN :

116. DAVE:

177. FREYMN :

II8. DAVE:

119. FREYMNN :

120. JOHN :

121. FREYMN :

122. JOHN:

123. FREYMLN :

124. MOUNT:

125. FREMLN :
Can you can other things by the same process wc used for tho tomatoes?

Only acid fruits and vegetables. For most other vegetablos or meats ycu need a pressure cocker. and yuu can't get then now.

Quite a fow are now on the rarket. But if you can't buy them-maybe you can find a fricnd who will share the use of a pressure cooker-a sort of fond club arrangcrent.

Does it tell about all nothods of canning in the Grvemment leaflet "CANNING IN THRTIE"?

It certainly does $\rightarrow$ nd in plain simple language... (TRINSITION) Oh, Johnny, Johnny Smith. Yes... too late to help with the canning, but with a guest ycu'Il mant to nect. The lady you promised wuld Give us some authentic informaticn on food group tro of the seven basic food groups?

Yes, Miss Maric Mount, chairman of the Maryland State Nutrition Comittee and also Dean of the C Ilege of Hone Econonics at the University of Maryland.

A pleasure to noet you, liss Mount-and I've heard a Iot f nice things about the fine job your MaryIand State Nutrition Committec is doing. Thank y u, Mrs. Freyman. Wiss Hount, just what are the foods in Group tro of the Basic Seven? 

126: MOUNT:

127. FRETMAN:

128. MOUNT :

129. FRETMAN:

130. MOUNT:

13i. FREMAN:

132. MOTNT:
They include tomatoes, citrus fruits, cabbage, pimentoes and the so-called salad greens.... lettuce cress, parsley, chicory and such. All of them foods which have a particular appeal during the surmer when cooling, fresh dishes do se much to tempt the appetite. What's the importance of these foods in the dietary scheme?

That's a very large question....too large for a detailed answer. But, trying to highlight the foods in this group.....some of them, the citmus fruits and tomatoes, particularly, are very rich sources of Vitamin $\mathrm{C}$. Rich in Vitamin C. Yes, and Vitamin C is one of the vitamins that can't be stored in the body. You have to eat it regularly to keep in good health. Now, while you can't store this vitamin in the body..... it can be canned.... by the process you outlined for tomatoes. Tomatoes, properly canned are good sources of this vitamin-as are canned tomato and citrus fmuit juices. What about the food values of cabbage and the salad greens?

Aside from their vitamin content... which is in itself important....these foods are generally good sources of needed minerals.... particularly calcium, phospherous and iron. These minerals are so important that wi thout them-human life stops. 

133. FRETIAN :

134. MOUNT :

135. FREMAN :

136. MOUNT :

137. FREMMAN :

133. MOUNT:

139. FREMIAN :
I know calcium is pretty important.

Yes, the bone structure and the teeth are dependent upon a proper supply of calcium in our food. Too little calcium means bad bones, poor teeth... a great variety of ills. Calcium is also necessary in the pumping action of the heart.

Phosphorous seems like, a funny body chemical. Didn't old time natches used to be made of phosphorous?

I think so-but it was a far different type of phosphorous compound than the phosphorous compounds we use-and must have--in the body.

The phosphorous which the body must have is in the forn of very complex organic chemical compounds. It is also important in bones and teeth. Iikewise, it plays a vital part in many other body processes. There does the iron fit in?

Probably its best know function is in connection with our blood.... the red hemoglobin. If the iron content drops too low, wie suffer with anemia-and possibly a lot of other ills. This iron, which the body uses, must also be obtained in complex organic forms-largely from food. You can't just try to eat the iron used in making nails or girders and expect it to help nourish the body.

If the complex iron compounds wich we need were reduced to metallic iron.....about how much actual iron no uld there be in a human body? 

140. MOUNT:

141. FREMAN :

142. MOUNT:

143. FREMARN:

144. IOUNT :

145. FREMAN:

146. MOUNT:
Only about one-seventh of an ounce. But don't be deceived by the sceming smal Iness of that amount-because if you didn't have it-or much of it-you wouldn't be alive. These minerals, calcium, phosphorous and iron-from foods-are absolutely essential. to human life and woll being. Then, foods in this Group Two are largely protective foods?

That is correct. Right now, too, they are relatively abundant and relatively cheap--except the citrus fruit group.

Then it is just good common sense to eat plenty of them now.

It is good sense to eat plenty of them now-and regularly. Canning will do much toward insuring the regularity--because most of these foods can have their soodness and their nutritional values saved for later times--rhen they are neither so abundint nor so cheap--by canning.

A pressure cooker is required for quite a few of these foods, isn't it?

Yes, for alloxcept the acid fruits and vegetables, a prossure cooker is a must. Oven canning is not satisfactory-nor is the so-called open kettle process. If you don't have-and cen't bur a pressure cooker-possibly you can borrow one from one of your good neighbors. Another possibility is to use one of the community canning kitchens--or food preservation 

146. MOUNT(CONT.): centers-which are in operation in many urban and rural areas. In any event--make every effort to obtain the use of a pressure cooker because we must save our foods-and pressure cooking is imperative for so many foods--which can be satisfactorily canned only by that process.

147. FREMAIT:

This folder, WARTIE CANIING OF FRUITS AID VEGETABIES gives the directions for both pressure cookery and the hot wator bath method.

148. MOUNT:

Stick to the directions in that folder-and your canning vill turn out the way you want it to. That is a good, simple and practical canning guide.

149. FREMAN : I certainly want to thank you for being with us todaj, Miss lifount.

150. MOUIT:

It was a pleasure and I urge canning-minded listeners to write in for that helpful leaflet, wARTIE CANIING OF FRUITS AID VEGTABIES.

15I. FREMANI:

152. JOHN : Just give your name, address and radio station call letters. The leaflet is sent without charge. Address your request to CONSUIER MINE, Whar Food Administration, Wrshington, $25, \mathrm{D}$. C.

153. FREYMAIT: That's the up to the minute ration stamp news, Johnny?

154. JOHN : 

155. FREYMAN :

156. JOHN:

157. FREYIAN :

158. JOHN :

159. FREYMAN:
What are you planning for next week, Johnny?

I've been digging around in potatoes and onions--and

a great collection of other vegetables and fruits which comprise Group Three of the Seven Basic Food Groups.

Sounds very tasty.

Hope it will be-and don't forget to write today for

your leaflet on Wartime Canning of Fruits \& Vegetables It'Il be a handy guide right along.

I won't forget. See you next week on CONSUIRR TINE. 

160. ANNOUNCER:

For your copy of Wartime Canning of Fruits and

Vegetables, send a post card--rith your name, address and radio station, to CONSUNER TIME, WTar Food Administration, Nashington (25) D. C. It will be sent without charge.

Heard on today's program were......

and Miss Marie lount, Chairmen of the Maryland State Nutrition Committee and Dean of the College of Horne Economics, ifaryland University.

Script by Granville Dicley

CONSURER TIRE is a public service of NBC and its affiliated radio stations, presented by the $\operatorname{Tar}$ Food Administration and other Government agencies working for consumors.

CONSUMER TINE has come to you from rashington. This is the National Broadcasting Company. 
